PAEDAGOGIA ChristianA

2/24 (2009) - ISSN 1505-6872

Piotr Stolecki*

Lipno

\title{
Obraz siebie u dziewcząt po doświadczeniu traumy
}

Z badań przeprowadzonych w Stanach Zjednoczonych wynika, że ponad $50 \%$ populacji przeżyło co najmniej jedno wydarzenie traumatyczne w ciagu życia i że u części tych osób - odsetek ten zależy od rodzaju traumy oraz odstępu czasu od ostatniego zdarzenia traumatycznego - występują zaburzenia rozpoznane jako zespół stresu pourazowego ${ }^{1}$.

Prekursorem badań nad traumą był Da Costa, który już w 2. połowie XIX wieku opisywał zaburzenia w postaci palpitacji serca, nudności, problemów ze snem, obserwując żołnierzy wojny secesyjnej. I i II wojna światowa ponownie uczyniły ten temat aktualnym, kiedy okazało się, że około $7-10 \%$ oficerów i 3-4\% pozostałych żołnierzy przeżyło załamanie nerwowe, związane z tzw. szokiem artyleryjskim. Badania ofiar Holocaustu wykazały ponadto, że wiele osób, które przeżyły obozy koncentracyjne, przejawiało zaburzenia psychosomatyczne i cierpiało z powodu lęków i koszmarów sennych. Kolejne badania przeprowadzono wśród weteranów wojen w Korei oraz Wietnamie a także wśród ofiar pożarów, powodzi, wypadków lokomocyjnych. W latach 70-tych opisano po raz pierwszy ,syndrom traumy gwałtu” oraz opublikowano pierwsze prace, dotyczące przemocy wobec dzieci i kobiet w rodzinie 2 .

W 1980 roku do DSM-III (Diagnostic and Statistical Manual of Mental Disorders), wydawanego przez Amerykańskie Towarzystwo Psychiatryczne (APA), dodano nową jednostkę chorobową, określaną jako zaburzenie po stresie traumatycznym (PTSD - posttraumatic stress disorder). W 1994 roku w kolejnej wersji DSM-IV wprowadzono jeszcze jedną jednostkę diagnostyczną - zespół

* Piotr Stolecki, mgr psychologii, mgr lic. teologii, doktorant psychologii KUL.

${ }^{1}$ Por. M. Lis-Turlejska, Stres traumatyczny. Występowanie, następstwa, terapia, Warszawa 2002, s. 8-9.

${ }^{2}$ Por. B. Dudek, Zaburzenie po stresie traumatycznym, Gdańsk 2003, s. 12. 
ostrego stresu (ASD - acute stress disorder), w którym przyjmuje się identyczną jak w PTSD definicję traumatycznego stresu, przy czym kryterium czasu wystąpienia objawów po traumie wynosi tutaj od 2 do 4 tygodni ${ }^{3}$.

Jednym z problemów badań osób po doświadczeniach traumatycznych jest związek przeżyć z osobowością. Stres jako taki, a w szczególności traumatyczny, pozostawia bardziej lub mniej trwały ślad w psychice ludzkiej - tak w sferze emocji, relacji interpersonalnych, jak i w sferze poznawczej, której przejawem funkcjonowania jest między innymi wiedza o sobie, składająca się na obraz siebie. Obraz siebie jest wiedzą płynącą z wewnętrznych doświadczeń siebie - swojego ciała, myśli, jak również z różnych sytuacji życiowych w kontakcie z otaczającą rzeczywistością; wiedzą zatrzymaną w pamięci i wciąż uaktualnianą, która poddawana jest procesom wartościującym i oceniającym. Środowisko, w jakim człowiek żyje, stanowi jeden z czynników kształtujących wiedzę o sobie, ustosunkowanie do samego siebie. I chodzi tutaj nie tylko o opinie innych ludzi na nasz temat. Także pewne wydarzenia, w których uczestniczymy, pozostawiaja ślad w pamięci i w zależności od ich charakteru i intensywności przeżywania umacniają nas i nasze myślenie o sobie albo wręcz przeciwnie - dezintegrują. W grupie zdarzeń negatywnie wpływających na obraz siebie znajdują się właśnie przeżycia traumatyczne. Autorzy zajmujący się tą problematyką wskazują szczególnie na zmiany w samoocenie, obniżenie poczucia wartości, obwinianie się, nieadekwatną ocenę swoich możliwości - jako objawy pozostające w związku $\mathrm{z}$ zaistniałą traumą.

Wśród licznych zmian w osobowości u osób po doświadczeniu stresu wymienić można także obraz siebie, a szczególnie jeden z jego aspektów - samoocenę. Doświadczanie negatywnych emocji, wywołujących reakcję stresową, ma związek z nasileniem się ujemnej postawy emocjonalnej wobec siebie i brakiem zaufania do siebie oraz innych. Stąd też w sytuacji przeciążeniowej, jaką z pewnością jest trauma, człowiek może przyswajać informacje niespójne z posiadanym obrazem siebie. To tylko jedna $\mathrm{z}$ wielu możliwości wpływu trudnych doświadczeń w obszarze oceny i rozumienia siebie ${ }^{5}$.

Ustosunkowanie się do siebie posiada element emocjonalny. Rolę emocji w kształtowaniu obrazu siebie akcentują teorie humanistyczne i psychodynamiczne. Kiedy nie ma dobrze wykształconych struktur poznawczych - jak w przypadku małych dzieci, emocje, odczucia odgrywają pierwszoplanową rolę. Aby ukształtował się adekwatny i stabilny obraz siebie, muszą być zaspokojone podstawowe potrzeby: bezpieczeństwa, akceptacji, bezwarunkowej miłości. Kiedy natomiast przeważają emocje negatywne, związane chociażby ze stresami, napięciami, wtedy też wzrasta prawdopodobieństwo, że utrwalą się ujemne postawy emocjonalne wobec siebie, obniżenie aspiracji, zmiany planów. Wtedy

3 Tamże, s. 14-15.

${ }^{4}$ Por. J. F. Terelak, Stres psychologiczny, Bydgoszcz 2001, s. 260.

5 Tamże, s. 287. 
też w ,ja" indywidualnym mogą pojawić się schematy własnej nieudolności, pechowości i braku zaufania tak do siebie, jak i do innych ${ }^{6}$.

W polskiej literaturze psychologicznej tematem traumy zajmowali się psychologowie i psychiatrzy w kontekście badań nad wpływem konkretnego rodzaju stresora na funkcjonowanie ludzi oraz w celu opracowywania metod diagnostycznych. Wśród autorów można wymienić: M. Lis-Turlejską, zajmującą się problematyką teorii, metod badania PTSD oraz współzależności stresu po traumie i uzależnienia od alkoholu oraz epidemiologią zjawiska w populacji studentów; B. Dudka ${ }^{8}$, badającego między innymi stres traumatyczny w kontekście zawodów szczególnego ryzyka: strażaków, policjantów; J. Strelaua9 i jego współpracowników, zajmujących się traumą u ofiar powodzi w kontekście uwarunkowań osobowościowych.

\section{Problematyka badań wlasnych}

W polskiej literaturze psychologicznej zagadnienie powiązań stresu z obrazem siebie nie było przedmiotem wielu opracowań. Psychologiczny kontekst badań pozwala na następujące sformułowanie problemu: czy i jakie różnice w zakresie obrazu siebie występują u dziewcząt, które doświadczyły stresu traumatycznego? Tak ujęty problem można uszczegółowić za pomocą następujących pytań badawczych:

- czy obraz siebie u dziewcząt po traumie różni się od obrazu siebie dziewcząt, które nie doświadczyły tego typu zdarzeń?;

- czy można wyróżnić charakterystyczne cechy ich koncepcji siebie w zakresie wymiarów wewnętrznych, takich jak: tożsamość, zadowolenie z siebie, ocena swojego postępowania oraz wymiarów zewnętrznych, takich jak: self fizyczny, moralny, rodzinny, społeczny, osobisty?;

- czy u dziewcząt po traumie wzrasta tendencja nasilenia występowania zaburzeń osobowości, zaburzeń psychotycznych oraz zwiększa się nasilenie neurotyzmu?

W świetle omawianych wcześniej wyników badań można także postawić następujące hipotezy. Hipoteza ogólna: doświadczenie traumy i obecność zaburzeń po stresie traumatycznym (PTSD) modyfikują obraz siebie. Hipotezy szczegółowe: osoby po traumie z symptomami PTSD: H. 1) charakteryzują się zaniżoną

${ }^{6}$ Por. A. Gałkowska, Percepcja powodzenia matżenstwa rodziców a społeczny obraz siebie ich dzieci, Lublin 1999, s. 68.

${ }^{7}$ M. Lis-Turlejska, dz. cyt., s. 82.

${ }^{8}$ B. Dudek, dz. cyt., s. 97.

9 Por. J. Strelau, B. Zawadzki, W. Oniszenko, A. Sobolewski, P. Pawłowski, Temperament $i$ style radzenia sobie ze stresem jako moderatory zespolu stresu pourazowego w nastęstwie przeżytej katastrofy, w: J. Strelau (red.), Osobowość a ekstremalny stres, Gdańsk 2004, s. 48-64. 
samooceną i obniżonym poczuciem własnej wartości; H. 2) posiadają niespójny obraz siebie; H. 3) cechują się wyższym natężeniem neurotyzmu oraz nasilonym występowaniem nieprawidłowości osobowości i symptomów zaburzeń, które obejmują poczucie regresji moralnej oraz negatywnej oceny siebie.

\section{Metody}

W realizowanym programie badawczym wykorzystano dwie metody psychologiczne - natężenia stresu traumatycznego ujętego za pomocą K-PTSD, natomiast do badania obrazu siebie wykorzystano Tennessee Skalę Obrazu Siebie.

Metoda K-PTSD opracowana została przez J. Koniarka, B. Dudka i M. Szymczak $^{10}$ na podstawie wersji Watsona PTSD-Interview. PTSD-I jest techniką badawczą, kwestionariuszową, składającą się z trzech części: 1) pytania o to, czy osoba badana doświadczyła zdarzenia traumatycznego, a jeśli tak, prośby o jego opis, który ma wykazać, czy rzeczywiście zdarzenie to nosiło znamiona przerażenia, strachu, niemocy, czyli stresu; 2) siedemnastu pytań o częstość lub intensywność występowania symptomów charakterystycznych dla PTSD, pogrupowanych w trzy kategorie: unikanie (7 pytań), pobudzenie (6 pytań), nawracanie (4 pytania). Badany daje odpowiedź na pytania w skali $1-6$, gdzie 1 oznacza - wcale, nigdy, a 6 - bardzo silnie, zawsze; 3 ) dwóch pytań pozwalających stwierdzić, czy symptomy utrzymywały się przez co najmniej miesiąc i czy aktualnie nadal się utrzymują.

Aby można było mówić o zaburzeniu po stresie traumatycznym, twórcy PTSD-I uznali, że badany musi wskazać u siebie i zaznaczyć obecność symptomów w skali 1-6 co najmniej na 4 (co znaczy - w pewnym stopniu, dość często) w następujących kategoriach: nawracanie - minimum 1 symptom; unikanie - minimum 3 symptomy; nadmierne pobudzenie - minimum 2 objawy; objawy muszą utrzymywać się z częstotliwością kilka razy na tydzień przez okres miesiąca.

PTSD-I poddano badaniom psychometrycznym na grupie weteranów wojny wietnamskiej. Grupę badano dwukrotnie - współczynnik korelacji między nimi wyniósł $\mathrm{r}=0,95$, a współczynnik zgodności wewnętrznej alfa Cronbacha wyniósł 0,92 . Trafność diagnostyczną określono przez porównanie PTSD-I z Diagnostic Interview Schedule (DIS), a korelacja wyników całkowitych obu narzędzi wynosiła 0,94 .

W polskiej wersji opisywanej metody zmieniono jej formułę z ustrukturalizowanego wywiadu na kwestionariusz do samodzielnego wypełniania. Celem standaryzacji metody badaniami objęto 469 osób. Cały kwestionariusz osiągnął

${ }^{10}$ J. Koniarek, B. Dudek, M. Szymczak, Kwestionariusz do pomiaru zaburzeń po stresie traumatycznym - zastosowanie PTSD-Interviev Ch. Watsona i jego wspótpracowników w badaniach grupowych, „Przegląd Psychologiczny” 43 (2000), nr 2, s. 205. 
wysoką wewnętrzną zgodność - alfa Cronbacha $=0,92$ (dla skali nawracanie $=0,87$, dla skali unikanie $=0,74$, dla skali pobudzenie $=0,87$ ).

Wykorzystywana w badaniach metoda do pomiaru obrazu siebie została opracowana przez H. Fittsa w połowie lat 50. i nosi nazwę Tennessee Self Koncept Scale. Normalizację testu Fitts przeprowadził w 1965 roku na grupie 626 osób w wieku: 12-68 lat. Rzetelność testu dla obydwu wersji wyniosła od .60 do .92 , co wskazuje na prawidłową podstawę teoretyczną, według której selekcjonowano itemy.

Skala TSCS składa się ze 100 itemów, za pomocą których osoba dokonuje opisu siebie na pięciostopniowej skali, gdzie 1 oznacza - całkowicie fałszywe, 2 - raczej fałszywe, 3 - nie jestem zdecydowany, 4 - raczej prawdziwe, 5 całkowicie prawdziwe. Metodę można stosować zarówno do badań indywidualnych, jak i grupowych osób zdrowych i psychotycznych. Przeznaczona jest dla osób powyżej 12 lat.

Wersja poradniana, którą wykorzystano w badaniach, daje możliwość obliczenia wyniku ogólnego (WO), na który składają się wyniki wewnętrznych wymiarów: tożsamości (TO), zadowolenia z siebie (ZS), zachowania (ZA) oraz wyniki zewnętrznych wymiarów: selfu fizycznego (SF), selfu moralno-etycznego (SM), selfu osobistego (SO), selfu rodzinnego (SR), selfu społecznego (SS). Ponadto oblicza się zmienność wymiarów, rzetelność profilu a także skale kliniczne: obronę pozytywną (DP), ogólne nieprzystosowanie (GM), psychotyzm (PSY), zaburzenia osobowości (PD), neurotyzm (N), integrację osobowości (PI) ${ }^{11}$.

\section{Grupa badanych}

W badaniach uczestniczyły dziewczęta uczęszczające do klas maturalnych. Średnia wieku badanych wyniosła $M=18,58 ; \mathrm{s}=0,43$. Na podstawie badań w K-PTSD wyselekcjonowano dwie grupy badanych: grupę kliniczną oraz grupę kontrolną. Dokonując wyboru do pierwszej z grup, posłużono się następującymi kryteriami:

- do grupy klinicznej zakwalifikowane zostały dziewczęta, które miały w ciagu ostatnich pięciu lat w swoim życiu przynajmniej jedno wydarzenie traumatyczne;

- przez minimum miesiąc doświadczyły w związku z traumą dolegliwości, świadczące o wystapieniu zaburzenia po stresie traumatycznym.

Dzięki takiej procedurze z grupy 254 badanych udało się wyodrębnić grupę 29 dziewcząt, spełniających te kryteria (stanowiły one 11,42\% wszystkich badanych). Jeśli chodzi natomiast o dobór dziewcząt do grupy kontrolnej, to wyłoniono ją na podstawie następujących kryteriów:

${ }^{11}$ Por. Z. Uchnast, B. Pilecka, Skrócony podręcznik do testu TSCS, maszynopis, Katedra Psychologii Ogólnej KUL 1998, s. 2. 
- z grona pozostałych osób badanych wybrano te dziewczęta, które nie doświadczyły traumy i nie miały objawów zaburzeń po stresie traumatycznym;

- z grupy tej losowo wybrano 29 osób, aby w dalszych analizach statystycznych można było porównywać obydwie grupy.

$\mathrm{Na}$ oznaczenie wyodrębnionych grup zastosowano następujące skróty: GT - grupa kliniczna dziewcząt po traumie, GBT - grupa kontrolna, czyli dziewczęta bez doświadczeń traumatycznych. Kwestią istotną dla charakterystyki grupy klinicznej jest wskazanie źródeł stresu traumatycznego. Informacje te zawiera poniża tabela.

Tabela 1. Rodzaje wydarzeń traumatycznych w grupie klinicznej (GT)

\begin{tabular}{|l|c|c|}
\hline Rodzaj traumy & N & $\%$ \\
\hline Ofiara molestowania seksualnego & 1 & 3,45 \\
\hline Uszkodzenie ciała w wypadku lokomocyjnym & 1 & 3,45 \\
\hline Świadek śmierci innej osoby w wypadku & 1 & 3,45 \\
\hline Świadek nagłej śmierci rodzica & 6 & 20,67 \\
\hline Pogryzienie przez zwierzę & 1 & 3,45 \\
\hline Świadek morderstwa & 1 & 3,45 \\
\hline Świadek uszkodzenia ciała znanej osoby w napadzie & 2 & 6,90 \\
\hline Ofiara przemocy domowej - uszkodzenie ciała, zagrożenie życia & 8 & 27,58 \\
\hline Świadek gwałtu przyjaciółki & 1 & 3,45 \\
\hline Świadek przedawkowania narkotyków przez bliską osobę & 1 & 3,45 \\
\hline Ofiara napadu & 2 & 6,90 \\
\hline Znalezienie zwłok znanej osoby & 2 & 6,90 \\
\hline Ofiara w bójce & 2 & 6,90 \\
\hline Ogółem & 29 & 100,00 \\
\hline
\end{tabular}

Z tabeli 1 wynika, że największy odsetek traum stanowią te związane z sytuacjami domowej przemocy $(27,58 \%)$, takimi jak: bójki wywołane przez pijanego ojca, znęcanie się fizyczne i psychiczne ojca nad matką i dziećmi, usiłowanie dokonania zabójstwa przy użyciu ostrych narzędzi. Drugą grupę stanowią traumy związane ze śmiercią rodzica $(20,67 \%)$. Na kolejnych miejscach znalazły się wydarzenia związane z wypadkami lokomocyjnymi (w sumie ponad 10\%). Pozostałe traumy związane były ze znalezieniem zwłok znanej osoby $(6,90 \%)$, z byciem ofiarą napadu (6,90\%), molestowania seksualnego $(3,45 \%)$, świadkiem gwałtu $(3,45 \%)$, przedawkowaniem narkotyków przez koleżankę $(3,45 \%)$, ofiara pobicia $(6,90 \%)$, ofiarą dotkliwego pogryzienia przez domowe zwierzę $(3,45 \%)$. 
Tabela 2. Liczba wydarzeń traumatycznych w grupie klinicznej (GT).

\begin{tabular}{|l|c|c|}
\hline Liczba traum & N & $\%$ \\
\hline Jedno wydarzenie traumatyczne & 4 & 13,79 \\
\hline Więcej niż jedno wydarzenie traumatyczne & 25 & 86,21 \\
\hline Ogółem & 29 & 100,00 \\
\hline
\end{tabular}

Dane zawarte w tabeli 2 wskazuja, że zdecydowana większość dziewcząt (86,21\%) doświadczyła więcej niż jednego zdarzenia, które zdefiniowały jako traumę. Pozostałe 13,79\% badanych w tej grupie osób doświadczyły tylko jednego takiego wydarzenia.

Tabela 3. Rodzaj uczestnictwa w traumie grupy klinicznej (GT)

\begin{tabular}{|l|c|c|}
\hline Uczestnictwo w traumie & $\mathrm{N}$ & $\%$ \\
\hline Jako ofiara & 13 & 44,83 \\
\hline Jako świadek zdarzenia & 16 & 55,17 \\
\hline Ogółem & 29 & 100,00 \\
\hline
\end{tabular}

Z tabeli 3 wynika, iż ponad połowa $(55,17 \%)$ dziewcząt z grupy klinicznej (GT) uczestniczyła w zdarzeniu traumatycznym w roli świadka, a pozostała część dziewcząt była ofiarami takich zdarzeń (44,83\%).

Jeśli chodzi natomiast o strukturę rodziny, to dziewczęta w grupie klinicznej (GT) w połowie pochodziły z rodzin niepełnych $(48,28 \%)$, natomiast w grupie kontrolnej (GBT) z rodzin pełnych pochodziło 55,17\%. Podobnie wyglądają proporcje w obydwu grupach, jeśli chodzi o procent osób z rodzin zrekonstruowanych (10,34\% w grupie klinicznej i 13,79\% w kontrolnej).

\section{Analiza wyników badań}

Dla tak wyodrębnionych grup przeprowadzono analizy porównawcze wyników w teście TSCS Fittsa.

\section{Wskaźniki rzetelności uzyskanych profilów obrazu siebie}

TSCS posiada dwa wskaźniki, które określają postawę osób wobec badania ich obrazu siebie. Jeśli chodzi o samokrytycyzm (SK), to niskie wyniki otrzymują osoby, które nie przyznają się do typowych słabych stron człowieka i popełnia- 
nych błędów. Osoby takie są nastawione obronnie do świata i przedstawiają siebie zazwyczaj w pozytywnym świetle, stąd też można przypuszczać, że ich wyniki w TSCS są zawyżone. Wysokie wyniki wskazują na normalną zdrową otwartość i zdolność do samokrytycyzmu. Ale bardzo wysokie wyniki mogą wskazywać, że osoba utraciła zdolność do zachowań obronnych oraz szacunek do siebie.

Drugim wskaźnikiem jest rozkład odpowiedzi (RO), którego wynik jest interpretowany jako pomiar percepcji siebie. Niskie wyniki posiadają zazwyczaj osoby, które wybierają na skali ocen 3 (nie jestem zdecydowany). Osoby te przejawiają albo wysoki poziom braku zdecydowania w prezentacji siebie, albo też wysoki poziom ostrożności, stąd też małe są u nich możliwości uzyskania autentycznego obrazu siebie. Natomiast bardzo wysoki wynik może wskazywać na to, że osoba wybiera skrajne sposoby określania siebie, co może być wyrazem tego, że odpowiedzi nie traktuje poważnie albo są one impulsywne.

Wyniki średnie dla obu grup badanych, wskaźniki istotności różnic prezentuje tabela 4, natomiast wykres 1 przedstawia profil wyników średnich badanych na skali tenowej.

Tabela 4. Porównanie wskaźników rzetelności profilu obrazu siebie TSCS badanych z grupy klinicznej (GT) i kontrolnej (GBT)

\begin{tabular}{|l|c|c|c|c|c|c|}
\hline \multicolumn{1}{|c|}{ Grupy } & \multicolumn{2}{|c|}{$\begin{array}{c}\text { Grupa klniczna } \\
(\mathrm{GT})\end{array}$} & $\begin{array}{c}\text { Grupa kontrolna } \\
(\mathrm{GBT})\end{array}$ & \multicolumn{2}{c|}{ Test t-studenta } \\
\hline $\begin{array}{l}\text { Wskaźniki rzetelności } \\
\text { profilu }\end{array}$ & $\mathrm{M}$ & $\mathrm{SD}$ & $\mathrm{M}$ & $\mathrm{SD}$ & statystyka & $\begin{array}{c}\text { Istotność } \\
\text { dwustronna }\end{array}$ \\
\hline Samokrytycyzm & 50,38 & 8,74 & 48,10 & 7,04 & 1,09 & 0,279 \\
\hline RO5 & 52,62 & 15,47 & 53,45 & 11,12 & $-0,23$ & 0,82 \\
\hline RO4 & 57,34 & 17,87 & 57,90 & 13,14 & $-0,13$ & 0,89 \\
\hline RO3 & 47,41 & 9,10 & 48,45 & 9,40 & $-0,43$ & 0,67 \\
\hline RO2 & 47,45 & 10,57 & 41,07 & 9,33 & 2,44 & $\mathbf{0 , 0 1 8}$ \\
\hline RO1 & 45,93 & 10,50 & 49,21 & 8,57 & $-1,30$ & 0,20 \\
\hline
\end{tabular}

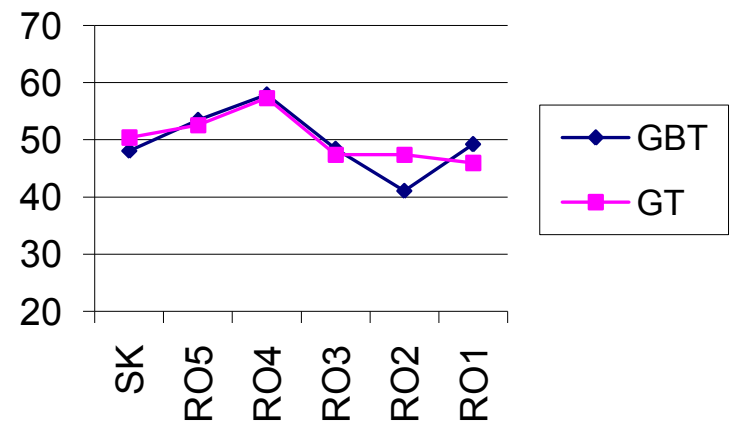

Wykres 1. Profile wyników średnich zawartych w tabeli 4 
$\mathrm{Z}$ danych przedstawionych $\mathrm{w}$ tabeli 4 i zobrazowanych na profilu 1 wyni$\mathrm{ka}$, iż samokrytycyzm (SK) nie różnicuje grup badanych na poziomie istotnym statystycznie. Zarówno w grupie kontrolnej (GBT), jak i klinicznej (GT) wyniki plasują się na poziomie wyników średnich, co wskazuje na obecność samokrytycyzmu u badanych.

Jeśli chodzi natomiast o rozkład odpowiedzi (RO), to tylko wyniki podskali RO2 różnicują grupy na poziomie istotnym statystycznie. W skali tenowej wyniki te, jak widać na wykresie 1, plasują się na poziomie wyników średnich. Dodając do tego jeszcze brak istotnych różnic w pozostałych podskalach RO1, RO3, RO4, RO5, można powiedzieć, iż rozkład odpowiedzi w obydwu grupach jest podobny. Oznacza to, iż dziewczęta po traumie, jak i bez traumy w podobny sposób wybierały odpowiedzi na skali 5-stopniowej. Pozwala to także sądzić, że odpowiedzi badanych nie były odpowiedziami przypadkowymi oraz że uzyskane wyniki odzwierciedlają sposób spostrzegania siebie.

\section{Obraz siebie w zakresie wymiarów wewnętrznych TSCS}

Można powiedzieć, że osoby, które uzyskują wyniki średnie lub wysokie w skalach wymiarów wewnętrznych, posiadają pozytywny obraz siebie. Mają one poczucie własnej wartości, które pozwala im siebie lubić, mieć do siebie zaufanie. Ponadto posiadają wysokie poczucie własnej tożsamości, samoakceptacji, są zadowolone ze swojego obrazu siebie. Natomiast osoby o wynikach niskich posiadają zaniżony obraz siebie, mają mniejsze zaufanie do siebie, mogą czuć się nieszczęśliwe, depresyjne.

Wyniki średnie dla grup badanych, wskaźniki istotności różnic prezentuje tabela 5, natomiast wykres 2 przedstawia profil wyników średnich badanych na skali tenowej.

Tabela 5. Porównanie obrazu siebie badanych dziewcząt $z$ grup: klinicznej (GT) i kontrolnej (GBT) w zakresie wymiarów wewnętrznych TSCS

\begin{tabular}{|l|c|c|c|c|c|c|}
\hline \multicolumn{1}{|c|}{ Grupy } & \multicolumn{1}{c|}{$\begin{array}{c}\text { Grupa kontrolna } \\
(\mathrm{GBT})\end{array}$} & $\begin{array}{c}\text { Grupa kliniczna } \\
(\mathrm{GT})\end{array}$ & \multicolumn{2}{c|}{ Test t-studenta } \\
\hline $\begin{array}{l}\text { Wymiary wewnętrzne } \\
\text { obrazu siebie }\end{array}$ & $\mathrm{M}$ & $\mathrm{s}$ & $\mathrm{M}$ & $\mathrm{s}$ & statystyka & $\begin{array}{c}\text { istotność } \\
\text { dwustronna }\end{array}$ \\
\hline Wynik ogólny & 33,86 & 9,87 & 46,52 & 7,76 & 5,43 & $\mathbf{0 . 0 0 1}$ \\
\hline Tożsamość & 30,93 & 11,16 & 44,86 & 10,04 & 5,00 & $\mathbf{0 , 0 0 1}$ \\
\hline Zadowolenie z siebie & 40,62 & 9,05 & 50,66 & 8,41 & 4,38 & $\mathbf{0 , 0 0 1}$ \\
\hline Zachowanie & 34,17 & 11,26 & 44,10 & 8,22 & 3,84 & $\mathbf{0 , 0 0 1}$ \\
\hline
\end{tabular}




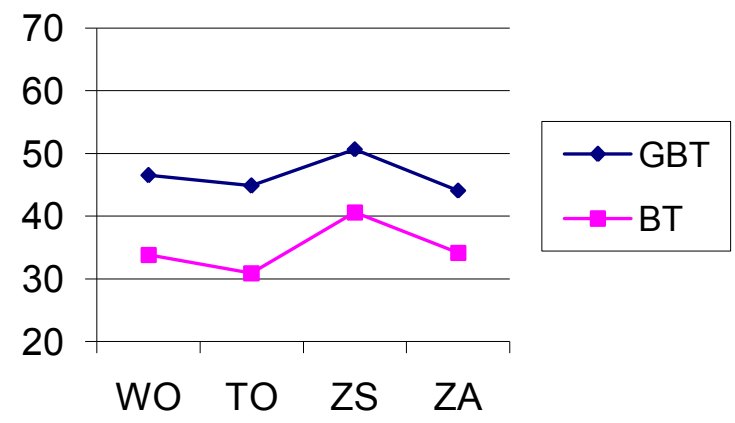

Wykres 2. Profile wyników średnich zawartych w tabeli 5

Wymiary wewnętrzne TSCS stanowią: wynik ogólny (WO), tożsamość (TO), zadowolenie z siebie (ZS) oraz zachowanie (ZA). Analizując wyniki z tabeli 5, można wywnioskować, że istnieją istotnie statystycznie różnice w obrazie siebie we wszystkich czterech wymiarach.

Wynik ogólny (WO) w grupie kontrolnej jest wyższy od wyniku w grupie klinicznej. Analizując go na skali tenowej - różnica ta stanowi 1 odchylenie standardowe. WO w grupie kontrolnej (GBT) mieści się w wynikach średnich, a w grupie klinicznej (GT) jest to wynik niski. Można stąd wnioskować, że obraz siebie dziewcząt po traumie w porównaniu do dziewcząt bez traumy charakteryzuje się znacząco mniej pozytywną oceną siebie. Stąd dziewczęta te mogą mieć mniejsze zaufanie do siebie. Mogą też czuć się niechciane, zalęknione, depresyjne, nieszczęśliwe.

Wynik TO (tożsamość) wyraźnie różnicuje grupy. Na skali tenowej, na której podawane są wyniki przeliczone TSCS, różnica ta przekracza jedno odchylenie standardowe i jest bardzo istotna statystycznie ( $p>0,001)$. Tożsamość w grupie kontrolnej (GBT) na skali plasuje się w sferze wyników średnich, a w grupie klinicznej (GT) jest to wynik niski. Można na podstawie tego wnosić, że dziewczęta po traumie doświadczają trudności w kształtowaniu własnej tożsamości. Stąd też mogą mieć problemy w określeniu tego, kim są, za kogo się uważają. Wzrasta też u nich niezgodność w odbiorze siebie oraz pełnionych przez siebie funkcji społecznych.

Także wyniki uśrednione w zakresie zadowolenia z siebie (ZS) wyraźnie różnicują grupy badanych. Różnica ta jest wielkości 1 odchylenia standardowego i jest statystycznie bardzo istotna. Wyniki u dziewcząt bez traumy (GBT) są na poziomie wyników średnich, a w grupie klinicznej (GT) są to wyniki niskie. Pozwala to wnioskować, że dziewczęta po traumie - w stosunku do dziewcząt bez traumy - posiadają znacząco niższy poziom samoakceptacji w sensie aprobaty siebie.

Grupy badane różnią się także istotnie statystycznie w kolejnym wymiarze obrazu siebie skali TSCS, jakim jest zachowanie (ZA). Wyniki grupy kontrolnej (GBT) w skali tenowej - to wyniki średnie, a w grupie klinicznej (GT) - wyniki niskie. Stąd też dziewczęta po traumie charakteryzują się bardziej negatywną oceną swojego zachowania i zdolności. W powiązaniu z niskimi wynikami we wcześniej omawia- 
nych wymiarach dziewczęta te mogą oceniać siebie jako mniej zdolne, o niesprecyzowanych planach życiowych, z mniejszą wiarą w siebie, mające problemy z osadzeniem się w rolach społecznych i wykonywaniem związanych z nimi zadań.

\section{Wymiary zewnętrzne obrazu siebie TSCS}

Wyniki skal ujmujących zewnętrzne wymiary obrazu siebie (ZW) są wynikami cząstkowymi wyniku ogólnego (WO). Stanowią je: self fizyczny (SF) - określa percepcję własnej fizyczności, stanu zdrowia, self moralno-etyczny (SM) - to samoocena ujmowana przez pryzmat zasad i wartości moralnych, self osobisty (SO) - określa poziom poczucia własnej wartości, niezależnie od ocen innych ludzi, oraz self rodzinny (SR) - określa ocenę poziomu adekwatności jako członka rodziny, czyli sposób spostrzegania siebie w relacji do bliskich sobie osób, jak również self społeczny (SS) - określa poziom poczucia własnej wartości w kontekście relacji do innych ludzi.

Wyniki średnie dla grup badanych, wskaźniki istotności różnic prezentuje tabela 6 , natomiast wykres 3 przedstawia profil wyników średnich badanych na skali tenowej.

Tabela 6. Porównanie obrazu siebie dziewcząt z grupy klinicznej (GT) i kontrolnej (GT) w zakre sie zewnętrznych wymiarów TSCS

\begin{tabular}{|l|c|c|c|c|c|c|}
\hline \multicolumn{1}{|c|}{ Grupy } & \multicolumn{2}{c|}{$\begin{array}{c}\text { Grupa kliniczna } \\
(\mathrm{GT})\end{array}$} & $\begin{array}{c}\text { Grupa kontrolna } \\
(\mathrm{GBT})\end{array}$ & \multicolumn{2}{c|}{ Test t-studenta } \\
\hline $\begin{array}{l}\text { Wymiary } \\
\text { obrazu siebie }\end{array}$ & $\mathrm{M}$ & $\mathrm{s}$ & $\mathrm{M}$ & $\mathrm{s}$ & statystyka & $\begin{array}{c}\text { istotność } \\
\text { dwustronna }\end{array}$ \\
\hline Self fizyczny & 35,55 & 10,85 & 45,52 & 10,37 & 3,58 & $\mathbf{0 , 0 0 1}$ \\
\hline Self moralny & 37,76 & 11,36 & 46,41 & 7,96 & 3,60 & $\mathbf{0 , 0 0 1}$ \\
\hline Self osobisty & 37,66 & 10,77 & 53,28 & 6,56 & 6,67 & $\mathbf{0 , 0 0 0 1}$ \\
\hline Self rodzinny & 35,72 & 9,42 & 45,90 & 8,60 & 4,30 & $\mathbf{0 , 0 0 0 1}$ \\
\hline Self społeczny & 41,66 & 10,70 & 45,93 & 7,29 & 1,78 & $\mathbf{0 , 0 8 1}$ \\
\hline
\end{tabular}

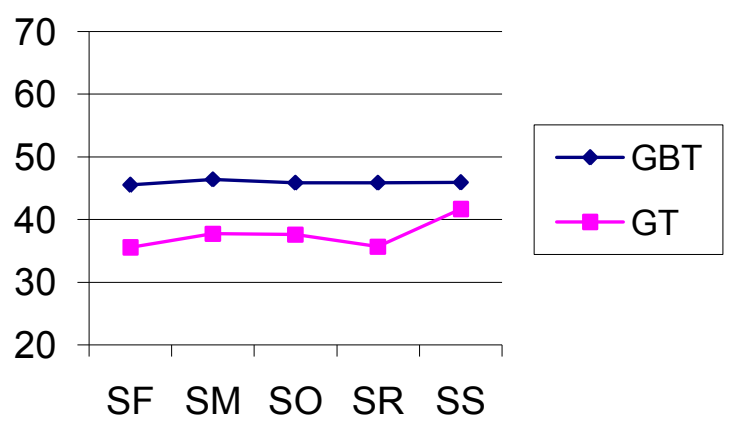

Wykres 3. Profile wyników średnich uzyskanych w tabeli 6 
Wszystkie średnie wyniki omawianych skal różnicują badane grupy na poziomie istotnym statystycznie (por. tabela 6). W skali selfu fizycznego (SF) wyniki grupy dziewcząt bez doświadczenia traumy (GBT) mieszczą się na poziomie wyników średnich skali tenowej, a u dziewcząt po traumie (GT) na poziomie wyników niskich. Taki rezultat badań wskazuje, iż osoby z grupy klinicznej mogą mieć trudności z akceptacją swojego wyglądu fizycznego, czując się nieatrakcyjnymi fizycznie, dostrzegając w swoim ciele wiele niedoskonałości, które stanowią przedmiot zmartwień. Warto też zaznaczyć, że dziewczęta po traumie moga mieć problemy z akceptacją swojej płci i seksualności.

W skali selfu moralno-etycznego wyniki w grupie kontrolnej (GBT) są wynikami średnimi, a wyniki w grupie klinicznej (GT) - niskimi. Różnica ta wynosi 1 odchylenie standardowe; jest też bardzo istotna statystycznie. Wnioskować zatem można, że dziewczęta po traumie mają w relacji do dziewcząt bez traumy zaniżoną samoocenę moralną. W związku z czym przeżywają siebie jako godne potępienia i moralnie złe. Poza tym mogą też częściej i intensywniej przeżywać różnego rodzaju kryzysy religijne, kryzysy wartości, podważając swój dotychczas ukształtowany stosunek do Boga.

Także i w zakresie skali selfu osobistego (SO) dziewczęta po traumie posiadają zaniżony obraz siebie, brakuje im poczucia własnej wartości, na co wskazują wyniki niskie w stosunku do średnich wyników dziewcząt $\mathrm{z}$ grupy kontrolnej (GBT). Stąd osoby z grupy klinicznej (GT) mogą znacznie częściej chcieć dostosowywać się do otoczenia wbrew swoim przekonaniom, przez co mają tendencję do uzależniania się od opinii innych.

Wyniki średnie w skali selfu rodzinnego (SR) także różnicują grupy na poziomie istotnym statystycznie. W skali tenowej różnice te przekraczają 1 odchylenie standardowe i są istotne statystycznie, wskazując tym samym, że dziewczęta $\mathrm{z}$ grupy osób po traumie (GT) w porównaniu z dziewczętami grupy kontrolnej (GBT) mają większą tendencję do nieadekwatnego funkcjonowania w rodzinie; mogą spostrzegać siebie jako osoby posiadające mniejszą wartość niż pozostali członkowie rodziny, a relacje z nimi mogą odbierać jako niewłaściwe.

Skala selfu społecznego (SS) także różnicuje grupy, ale w skali tenowej nie jest to różnica istotna statystycznie, gdyż obydwie grupy ze swoimi wynikami mieszczą się w przedziale wyników średnich, co wskazuje raczej na pozytywne spostrzeganie siebie w relacjach do ludzi w ogóle.

\section{Podsumowanie}

Realizowany program badawczy dostarczył danych o obrazie siebie u dziewcząt po stresie traumatycznym. Uzyskane wyniki pozwoliły dać odpowiedź na postawione pytania badawcze i zweryfikować hipotezy. Przypomnę, że hipoteza ogólna brzmiała: doświadczenie traumy i obecność zaburzeń po stresie traumatycznym (PTSD) modyfikuje obraz siebie u dziewcząt. 
Statystyczne opracowanie danych wskazuje, że potwierdzone zostały hipotezy sugerujące istnienie związku między traumą a obrazem siebie. Grupa badanych dziewcząt, które doświadczyły traumy i miały zaburzenie po stresie traumatycznym (GT), w porównaniu do dziewcząt bez doświadczenia traumy (GBT) charakteryzuje się w zakresie obrazu siebie posiadaniem małego zaufania do siebie, dziewczęta czują się także niechciane, zalęknione, depresyjne, nieszczęśliwe. Poza tym mogą mieć problemy w określeniu tego, kim sa, za kogo się uważają; posiadają niższy poziom samoakceptacji, przeżywają siebie jako mniej zdolne, o niesprecyzowanych planach życiowych, z zaniżoną wiarą w siebie, również jako niewierzące w swój sukces. Ponadto nie akceptują swojego wyglądu fizycznego, czując się nieatrakcyjne fizycznie, mogą mieć też problemy z akceptacją swojej płci i seksualności. Dziewczęta z grupy klinicznej (GT) charakteryzują się zaniżoną samooceną moralną, oceniając siebie jako moralnie złe; mogą też częściej i intensywniej przeżywać różnego rodzaju kryzysy religijne; mogą znacznie częściej chcieć dostosowywać się do otoczenia wbrew swoim przekonaniom, wykazując tendencję do uzależniania się od opinii innych. Są także skłonne do negatywnej oceny swego postępowania, spostrzegając siebie jako osoby posiadające mniejszą wartość niż pozostali członkowie rodziny, choć w relacjach z innymi ludźmi (poza rodzina) mogą pozytywniej oceniać swoje postępowanie; wykazują tendencję do rozczłonkowywania poszczególnych aspektów obrazu siebie i oceniania ich niezależnie od siebie.

Dziewczęta po traumie cechują się również wyższym poziomem neurotyzmu. Można to zinterpretować jako trudność w integrowaniu obrazu siebie i czynienia go strukturą w miarę spójną i klarowną. Może to także być wyrazem utrzymywania się poczucia rozproszenia, wyrażającego się dezorientacją co do tego, kim się jest. U dziewcząt z grupy klinicznej (GT) wzrasta poza tym możliwość występowania zaburzeń osobowości. Posiadają mniejsze zdolności do zachowań obronnych i odzyskania szacunku do siebie.

Z przeprowadzonych badań dają się wyprowadzić także wnioski ważne dla poradnictwa psychologicznego i pracy z młodzieżą. Okres dorastania z uwagi na specyfikę zachodzących wtedy zmian, kształtowanie się tożsamości poddawane są refleksji zarówno teoretyków, jak i praktyków, nie tylko w dziedzinie psychologii. Wyniki badań przedstawione w tym opracowaniu zwracały uwage na znacznie obniżony w wielu wymiarach obraz siebie osób z zaburzeniami po traumie. Stąd ważne wydają się:

- psychoedukacja, szczególnie rodziców, nauczycieli o skutkach przemocy domowej i konieczność przeciwdziałania rozwojowi zaburzeń po traumie - np. poprzez szybkie udzielanie wsparcia społecznego pod różnymi postaciami;

- szkolenie psychologów pracujących z młodzieżą, dotyczące interwencji w sytuacjach zaistnienia traumy, prowadzenia grup wsparcia, uczenia radzenia sobie ze stresem przez młodzież; 
- zwiększenie dostępności młodzieży do profesjonalnej pomocy psychologicznej, mającej na celu poprawę samooceny po trudnych, traumatycznych wydarzeniach, wspieranie procesu kształtowania tożsamości i przeciwdziałania jego zaburzeniom chociażby poprzez pracę nad patologicznym poczuciem winy.

\section{Self image of girls after traumatic stress (Summary)}

Among changes in personality after traumatic stress there are also changes connected with the self - image. Dynamics, the range of these changes are extremely crucial during the adolescence period, when one of the developmental task in gaining the suitable self - image. Researches on the girls with PTSD have been conducted and in the article the results are going to be presented. The clinic group $(\mathrm{N}=29)$ has been made up of 254 girls. It should be stressed that but for the questionnaire K-PTSD, this group world not have been formed. Furthermore, the scale TSCS has been helpful in conducting the researches. They have confirmed some hypotheses. Firstly, the people with disturbances after traumatic stress have low self - esteem and the incoherent self - image. Additionally, they may suffer from neurotic disturbances and the feeling of moral regression intensifies. 